\title{
Sensitivity of North American Isolates of Phytophthora erythroseptica and Pythium ultimum to Mefenoxam (Metalaxyl)
}

\author{
R. J. Taylor, B. Salas, G. A. Secor, V. Rivera, and N. C. Gudmestad, Department of Plant Pathology, North Da- \\ kota State University, Fargo 58105
}

\begin{abstract}
Taylor, R. J., Salas, B., Secor, G. A., Rivera, V., and Gudmestad, N. C. 2002. Sensitivity of North American isolates of Phytophthora erythroseptica and Pythium ultimum to mefenoxam (metalaxyl). Plant Dis. 86:797-802.
\end{abstract}

A 4-year study (1997 to 2000) was conducted to determine the sensitivities of the potato tuber rot pathogens, Phytophthora erythroseptica and Pythium ultimum, to mefenoxam (metalaxyl). A total of 2,277 tubers showing symptoms of "water rot" were collected from 16 states and 2 Canadian provinces. From these, 849 isolates of $P$. erythroseptica and 213 isolates of $P$. ultimum were obtained, and 805 and 190 isolates, respectively, were tested for their ability to grow on V8 medium amended at 0.01 to $100 \mu \mathrm{g} / \mathrm{ml}$ with fungicide. Isolates ranged widely in their responses to mefenoxam. The presence of resistant isolates $\left(\mathrm{EC}_{50}>100 \mu \mathrm{g} \mathrm{ml}^{-1}\right)$ of P. erythroseptica in the potato producing areas of Maine was confirmed. The presence of P. erythroseptica isolates in Idaho and Minnesota resistant to mefenoxam is reported for the first time. The proportion of $P$. erythroseptica isolates resistant to mefenoxam varied from 2.9 to $36.2 \%$ between 1997 and 2000. The proportion of resistant P. ultimum isolates represented only a small proportion of the isolates tested (3.7\%). A single resistant $P$. ultimum isolate was recovered from Washington, whereas most of the resistant isolates obtained (5 of 7) were collected in Minnesota during the final year of the study. This is the first report of resistance in P. ultimum pathogenic to potato tubers. These observations suggest that pink rot and leak could become significant problems in the future, particularly in those areas where resistance has been detected. Our results have implications for the effective management of water rot. Monitoring the sensitivity of the pathogen population to mefenoxam in all production areas should be considered and integrated as a part of the overall disease management strategy.

Additional keywords: fungicide resistance, leak, pink rot, potato, Ridomil, Solanum tuberosum

Since their introduction in the late 1970s, phenylamide fungicides have been used effectively to control diseases caused by the Peronosporales. These fungicides have a very specific mode of action; inhibiting fungal ribosomal RNA polymerases (7). Because of this specificity, there is a relatively high risk that resistance to the fungicide may appear quickly in the target fungal population (3). Phenylamides were used initially as a straight product (unaccompanied by a second fungicide) and as a result, within 2 years of their introduction, insensitive isolates of Pseudoperonospora cubensis were collected from cucumber in Israel (33), and isolates of Phytophthora infestans insensitive to metalaxyl also were found in potato crops in Ireland (9) and the Netherlands (8). A short time later, resistance was documented in a variety of Oo-

Corresponding Author: Neil C. Gudmestad

E-mail: Neil.Gudmestad@ndsu.nodak.edu

Current address of second author: Department of Plant Pathology, University of Minnesota, St. Paul, 55108.

Accepted for publication 8 March 2002

Publication no. D-2002-0503-01R

(C) 2002 The American Phytopathological Society mycete species from diverse crops (grapes, lettuce, tobacco, and turf). Morton and Urech (25) reviewed these and other reports of the initial development of resistance to this class of fungicides.

Phenylamide fungicides have been used primarily to control foliar diseases since the initial Environmental Protection Agency (EPA) conditional registration of metalaxyl on tobacco in 1980 (25). Resistance to metalaxyl was first found in North America in 1984 when this fungicide failed to control Pythium turf blight in Pennsylvania (35). Most of the information gathered on resistance in North America has come from studies involving foliar pathosystems. As phenylamides lost their effectiveness in controlling some foliar diseases, their use against soilborne diseases has increased. This poses a potential problem since resistance probably would develop under these conditions as well (41), although this is likely to occur at a slower rate due to the monocyclic nature of most soilborne pathogens. Intrasite and intersite movement of resistance also should be slower in this group.

Two important soilborne diseases of potato, pink rot and leak, often collectively known as "water rot", are caused by the Oomycetes, Phytophthora erythroseptica and Pythium ultimum, respectively. Either disease can be found during or immediately following harvest, especially in areas and in years with high moisture $(14,20)$. Pink rot and leak can be widely distributed in potato fields and storage bins $(31,36)$. Strategies commonly used to manage water rots include crop rotation, planting the potato crop in well-drained soils, avoiding excessive irrigation at the end of the growing season, modifying handling procedures to reduce wounding, and applications of mefenoxam (31,36). Most commonly grown potato cultivars are susceptible to $P$. erythroseptica and Pythium ultimum (authors, unpublished data) so resistance is not currently a practical control measure for the water rot diseases.

Mefenoxam (Ridomil Gold EC and Ultrafluorish EC) is the only fungicide used to control pink rot and leak $(26,43)$. The effectiveness of this fungicide may be compromised if insensitive isolates of $P$. erythroseptica and Pythium ultimum become widespread. Currently, mefenoxamresistant isolates of $P$. erythroseptica are known to be present in Maine, New York, and Idaho $(13,15,23)$. This and recent outbreaks of pink rot in the Red River Valley of North Dakota and Minnesota (24) have caused concern among growers and industry representatives. Aside from our preliminary reports $(15,16,34,38)$, a thorough survey of the incidence of resistance to phenylamide fungicides in populations of the water rot fungi has not been conducted. The objective of this study was to determine the level of sensitivity to mefenoxam in isolates of P. erythroseptica and Pythium ultimum collected throughout North America and to monitor the distribution of these isolates.

\section{MATERIALS AND METHODS}

Tuber samples and isolations. Tubers with symptoms of water rot were collected from commercial potato fields and storages, and shipped to our laboratory for analysis. Isolations were made by placing small pieces $(4 \times 4 \mathrm{~mm})$ of infected tissue in petri dishes containing water agar amended with ampicillin $\left(100 \mu \mathrm{g} \mathrm{ml}^{-1}\right)$, and incubated in darkness at 17 to $20^{\circ} \mathrm{C}$ for 3 to 5 days. Fungal colonies with mycelia resembling those of $P$. erythroseptica or Pythium spp. were selected and purified by hyphal tipping. All isolates were identified based on morphological characteristics given by Ho and Jong (17) for P. erythroseptica and the key for Pythium spp. found in Plaats-Niterink (28). A number of 
isolates from California, Oregon, and Washington were received in 1999 as a group collection made by P. Hamm (Oregon State University, Corvallis) between 1996 and 1998. The selective medium $\mathrm{P}_{5} \mathrm{ARPH}$ (19) was used to isolate P. erythroseptica from badly rotted tubers or from tuber samples arriving in late fall or winter. Isolates of $P$. erythroseptica were maintained on clarified V8 juice agar medium (10\% V8 juice filtered through four layers of cheesecloth, $0.1 \% \mathrm{CaCO}_{3}$ and $2 \%$ agar) and those of Pythium spp. were kept on corn meal agar (CMA).

Fungicide sensitivity testing. The effect of metalaxyl (Ridomil 2E WPS) in 1997 and mefenoxam (Ridomil Gold 4EC) in 1998 to 2000 on mycelial growth in vitro was determined on modified $V 8$ juice agar $(5 \% \mathrm{~V} 8$ juice filtered through four layers of cheesecloth and 2\% agar). Fungicide was incorporated into the medium in a 10-fold dilution series ranging from 0.1 to $100 \mu \mathrm{g} \mathrm{ml}^{-1}$ (1997 and 1998) and 0.01 to $100 \mu \mathrm{g} \mathrm{ml}^{-1}$ (1999 and 2000) before autoclaving. The test culture plates were stored in darkness at room temperature (20 to $25^{\circ} \mathrm{C}$ ) for 3 days prior to use to minimize photodegradation of the fungicide. Isolates with $50 \%$ effective concentration $\left(\mathrm{EC}_{50}\right)$ values greater than $100 \mu \mathrm{g} \mathrm{ml}^{-1}$ were retested up to $300 \mu \mathrm{g} \mathrm{ml}^{-1}$ in follow-up trials in 1999 and 2000.

Mycelial plugs, $5 \mathrm{~mm}$ in diameter, were cut from the margin of actively growing colonies of 4- to 6-day-old cultures of $P$. erythroseptica on clarified $10 \%$ V8 juice agar as described above. One plug was positioned in the center of a 9-cm culture dish with the mycelium in contact with the medium. Duplicate culture dishes, each containing $17 \mathrm{ml}$ of test medium, were used to test each isolate at each concentration. In the tests of Pythium ultimum isolates, 48-h-old cultures were used. Pathogenicity of the Pythium isolates was determined prior to testing and only those isolates capable of infecting potato tubers were tested for their sensitivity to mefenoxam.

Growth of isolates at each concentration was determined by measuring colony diameters in two perpendicular directions on each culture plate after 6 days $(P$. erythroseptica) and $36 \mathrm{~h}$ (Pythium ultimum) of incubation in darkness at $20 \pm 1{ }^{\circ} \mathrm{C}$. Measurements were averaged, and the diameter of the mycelial plug was subtracted $(30,41)$. The relative growth reduction for each rate of fungicide was calculated as follows: [100 - (growth with fungicide/growth in control plate)*100]. The concentration causing $50 \%$ relative reduction of mycelial growth $\left(\mathrm{EC}_{50}\right)$ compared to the control was estimated by plotting the percent inhibition against the log-scale of fungicide concentration (1997 and 1998) or by regression curve fitting (1999 and 2000). Individual sensitivity curves were generally sigmoid in shape unless the iso- lates were highly insensitive to the fungicide. Therefore, data sets were fit to nonlinear functions such as the logistic and Gompertz. Only the Gompertz function yielded solutions on a consistent basis. The Gompertz model is a 3 parameter sigmoidal function with the general form

$$
y=\alpha\left\{\exp \left[-\exp \left(\beta-\gamma^{*} x\right)\right]\right\}
$$

It has frequently been used in population studies and to model growth in animals and plants (10). Each of the parameters, or some monotonic transformation thereof, relates to aspects of the sigmoidal curve (32). As such, $\alpha$ is associated with the asymptote or maximum value, $\beta$ is associated with the $y$-intercept, and $\gamma$ relates to the rate at which the response increases as one proceeds from the initial value $(\beta)$ to the final value $(\alpha)$. Once obtained, data parameters were input into the Gompertz function and the $\mathrm{EC}_{50}$ was estimated by solving for the concentration at which $50 \%$ sensitivity would occur. In those cases where the Gompertz function would not yield estimates, a simple linear interpolation between the two concentrations bracketing $50 \%$ sensitivity was performed to estimate the $\mathrm{EC}_{50}$.

Comparative isolates. Mefenoxam sensitivity of 87 isolates of $P$. erythroseptica obtained from the culture collection of Robert W. Stack (Department of Plant Pathology, North Dakota State University, Fargo) was assessed during the final year of the survey. These isolates were collected at various locations approximately 5 years prior to the start of the current project (1991 and 1992) and were reported previously (38).

\section{RESULTS}

Survey. During the course of this study (1997 to 2000), a total of 2,277 tubers were obtained from 16 states and 2 Canadian provinces. Much of this material came from problem areas in fields treated with metalaxyl/mefenoxam. Isolates of $P$. erythroseptica were collected from $47.3 \%$ of the infected tubers, and $36.6 \%$ of the samples yielded isolates of Pythium ultimum. Tubers exhibiting symptoms of multiple infections were encountered during the survey, and pathogens such as Fusarium spp, Verticillium spp., Pythium spp., and various other "contaminating" microorganisms were occasionally recovered but these were discarded without further documentation. Based on symptomology, P. infestans was undoubtedly present in some multiple infections but attempts were not made to recover that pathogen. A total of 849 isolates of P. erythroseptica and 213 isolates of Pythium ultimum were recovered from pink rot $(1,750)$ and leak (527) infected tubers, respectively. Of these, 805 isolates of P. erythroseptica and 190 isolates of Pythium ultimum were subsequently tested for their sensitivity to metalaxyl/ mefenoxam.
Sensitivity of $P$. erythroseptica. Of the 69 isolates of $P$. erythroseptica tested in 1997 , only two with $E_{50}$ values $\geq 100 \mu \mathrm{g}$ $\mathrm{ml}^{-1}$ were identified (Table 1). These represented $2.9 \%$ of isolates tested and both were from Maine. The remaining $97.1 \%$ of the isolates fell into a wide grouping with $\mathrm{EC}_{50}<1.0 \mu \mathrm{g} \mathrm{ml}^{-1}$. No isolates with $\mathrm{EC}_{50}$ values between $1.0 \mu \mathrm{g} \mathrm{ml}^{-1}$ and $99.9 \mu \mathrm{g} \mathrm{ml}^{-1}$ were recovered in 1997.

A total of 137 P. erythroseptica isolates were tested in 1998. Most of the isolates, representing $83.9 \%$ of the total population from all sites, fell within the group with $\mathrm{EC}_{50}$ values in the $<1.0 \mu \mathrm{g} \mathrm{ml}^{-1}$ range. As in the previous year, eight isolates from Maine had $\mathrm{EC}_{50}$ values higher than $100 \mu \mathrm{g}$ $\mathrm{ml}^{-1}$. However, nine isolates from Idaho with $\mathrm{EC}_{50}$ values greater than $100 \mu \mathrm{g} \mathrm{ml}^{-1}$ were found for the first time. Isolates with high $\mathrm{EC}_{50}$ values $\left(>100 \mu \mathrm{g} \mathrm{ml}^{-1}\right)$ from these two states represented $12.4 \%$ of the total number tested in 1998. A small portion of the Maine and Idaho isolates $(3.6 \%)$ had $\mathrm{EC}_{50}$ values ranging between $10.0 \mu \mathrm{g} \mathrm{ml}^{-1}$ and $99.9 \mu \mathrm{g} \mathrm{ml}^{-1}$ (Table 1).

A total of 232 isolates were tested for mefenoxam sensitivity in 1999 . The results confirmed the presence of isolates with high $\mathrm{EC}_{50}$ values (in excess of $100 \mu \mathrm{g} \mathrm{ml}^{-1}$ ) in Idaho and Maine. In 1998, $19.6 \%$ of isolates from Idaho and $61.5 \%$ isolates from Maine fit this grouping. These proportions increased to 53.6 and $75.0 \%$, respectively, in 1999. Isolates with high $\mathrm{EC}_{50}$ values represented $27.2 \%$ of all isolates received from seven states that year. In contrast, more that half of the isolates $(71.9 \%)$ tested had $\mathrm{EC}_{50}$ values less than $1.0 \mu \mathrm{g} \mathrm{ml}^{-1}$, but this represented a lower proportion of the total population relative to 1998 .

In the final year of this study, we tested more isolates than in the first 3 years combined. Of these, the majority was received from Idaho and Minnesota. Again, isolates with $\mathrm{EC}_{50}$ values greater than $100 \mu \mathrm{g} \mathrm{ml}^{-1}$ were obtained from Maine $(60.0 \%)$ and Idaho $(43.2 \%)$, but 18 isolates with very high $\mathrm{EC}_{50}$ values from Minnesota were identified for the first time. This represented a substantial proportion $(21.4 \%)$ of the isolates tested from that state. The proportion of the total population with $\mathrm{EC}_{50}$ values in the lower grouping $\left(<1.0 \mu \mathrm{g} \mathrm{ml}^{-1}\right)$ was considerably lower in the latter 2 years of this study as sensitivity to mefenoxam shifted toward the $\geq 100 \mu \mathrm{g} \mathrm{ml}{ }^{-1}$ group (36.2\% of all isolates tested). More of the intermediate types $(9.3 \%$ of all isolates tested) were found than in the previous 3 years. All of these came from the three states having isolates with high $\mathrm{EC}_{50}$ values (Idaho, Maine, and Minnesota). Upon reassay, the sensitivities of isolates with $\mathrm{EC}_{50}$ values $\geq 100 \mu \mathrm{g} \mathrm{ml}^{-1}$ were found to range between $127 \mu \mathrm{g} \mathrm{ml}^{-1}$ and $184 \mu \mathrm{g} \mathrm{ml}^{-1}$ mefenoxam in the 1999 population and from $109 \mu \mathrm{g} \mathrm{ml} l^{-1}$ to $205 \mu \mathrm{g} \mathrm{ml}^{-1}$ in the 2000 population. 
Sensitivity of comparative isolates. None of the isolates collected in 1991 and 1992 was resistant to mefenoxam (Table 2 ). With the exception of a single isolate from Washington that fit into the lowest ranking category of the intermediate group $\left(\mathrm{EC}_{50}=1.56 \mu \mathrm{g} \mathrm{ml}^{-1}\right)$, all of the isolates tested were sensitive to mefenoxam. Nearly $30 \%$ of the isolates were highly sensitive, falling into the group with $\mathrm{EC}_{50}$ values $\leq 0.05 \mu \mathrm{g} \mathrm{ml}^{-1}$. This group represents a much greater proportion of the sample population than observed in the samples collected during the 4 years of this study. The proportion of highly sensitive isolates present in the population sampled during that time ranged from 7.3\% (1998 and 1999) to $10.1 \%$ (1997) (Table 1).

Sensitivity of Pythium ultimum. Only seven isolates of Pythium ultimum pathogenic to potato were recovered in the initial year of this study (1997), and because of the range of the dilutions selected to assess sensitivity we did not determine their exact $\mathrm{EC}_{50}$ values that year. These values were below $1.0 \mu \mathrm{g} \mathrm{ml}^{-1}$ because none of the isolates was able to grow at this concentration. During the 3 years of this study, 1998 to 2000, 190 isolates of the Pythium ultimum were screened, most of which $(94.2 \%)$ had $\mathrm{EC}_{50}$ values $<1.0 \mu \mathrm{g} \mathrm{ml}^{-1}$ (Table 3). A single isolate from Idaho with an $\mathrm{EC}_{50}>100 \mu \mathrm{g} \mathrm{ml}^{-1}$ was found in 1998 , but none was found in the 41 isolates tested in 1999. In 2000, six resistant isolates were found in the population of 93 tested. Of these, five came from Minnesota and one from Washington. The Washington isolate had an $\mathrm{EC}_{50}$ of $101 \mu \mathrm{g} \mathrm{ml}^{-1}$ and all five of the isolates from Minnesota tested were highly resistant to mefenoxam $\left(\mathrm{EC}_{50}>300\right.$ $\left.\mu \mathrm{g} \mathrm{ml} \mathrm{m}^{-1}\right)$. Resistance was not observed in the isolates recovered from Washington during 1998 and 1999, and only two isolates fitting the intermediate group were obtained from that state prior to 2000 .

\section{DISCUSSION}

Successful implementation of any fungicide resistance management program must include an assessment of the initial level of fungicide sensitivity, or "baseline" in the pathogen population. Numerous studies involving a variety of fungal pathogens have demonstrated that isolates can range widely in their responses to phenylamide fungicides $\quad(2,5,6,11-13,18,27,39,40,42)$. The 1,082 isolates tested in this study also varied markedly in their sensitivities to mefenoxam. Some isolates were extremely sensitive $\left(\mathrm{EC}_{50}\right.$ values below $\left.0.05 \mu \mathrm{g} \mathrm{ml}^{-1}\right)$, whereas others were extremely resistant $\left(\mathrm{EC}_{50}>100 \mu \mathrm{g} \mathrm{ml}^{-1}\right)$, and readily grew on

Table 1. Distribution and ranking of $\mathrm{EC}_{50}$ values of Phytophthora erythroseptica isolates collected during a survey (1997 to 2000) of infected tubers obtained from the United States and Canada

\begin{tabular}{|c|c|c|c|c|c|c|c|c|c|}
\hline \multirow[b]{3}{*}{ Year and source } & \multirow[b]{3}{*}{ No. isolates tested } & \multicolumn{8}{|c|}{ Distribution of isolate $\mathrm{EC}_{50}$ values $\left(\mu \mathrm{g} \mathrm{ml}^{-1}\right)$} \\
\hline & & \multicolumn{4}{|c|}{ Sensitive } & \multicolumn{3}{|c|}{ Intermediate } & \multirow{2}{*}{$\begin{array}{c}\text { Resistant } \\
\geq 100\end{array}$} \\
\hline & & $\leq \mathbf{0 . 0 5}$ & $0.06-0.1$ & 0.11-0.15 & $0.16-0.99$ & 1.0-1.99 & $2.0-9.9$ & $10.0-99.9$ & \\
\hline \multicolumn{10}{|l|}{1997} \\
\hline Idaho & 16 & 1 & 8 & 6 & 1 & 0 & 0 & 0 & 0 \\
\hline Maine & 3 & 0 & 1 & 0 & 0 & 0 & 0 & 0 & 2 \\
\hline Minnesota & 22 & 3 & 9 & 9 & 1 & 0 & 0 & 0 & 0 \\
\hline New Brunswick, Canada & 4 & 0 & 0 & 1 & 3 & 0 & 0 & 0 & 0 \\
\hline North Dakota & 24 & 3 & 8 & 11 & 2 & 0 & 0 & 0 & 0 \\
\hline Totals for year & 69 & 7 & 26 & 27 & 7 & 0 & 0 & 0 & 2 \\
\hline Frequency $(\%)$ & & $(10.1)$ & $(37.7)$ & $(39.1)$ & $(10.1)$ & $(0.0)$ & $(0.0)$ & $(0.0)$ & $(2.9)$ \\
\hline \multicolumn{10}{|l|}{1998} \\
\hline Idaho & 46 & 0 & 16 & 17 & 2 & 0 & 0 & 2 & 9 \\
\hline Maine & 13 & 1 & 1 & 0 & 0 & 0 & 0 & 3 & 8 \\
\hline Minnesota & 46 & 4 & 36 & 6 & 0 & 0 & 0 & 0 & 0 \\
\hline Nebraska & 6 & 3 & 3 & 0 & 0 & 0 & 0 & 0 & 0 \\
\hline North Dakota & 20 & 1 & 16 & 3 & 0 & 0 & 0 & 0 & 0 \\
\hline South Dakota & 1 & 1 & 0 & 0 & 0 & 0 & 0 & 0 & 0 \\
\hline Washington & 3 & 0 & 2 & 1 & 0 & 0 & 0 & 0 & 0 \\
\hline Wisconsin & 2 & 0 & 1 & 1 & 0 & 0 & 0 & 0 & 0 \\
\hline Totals for year & 137 & 10 & 75 & 28 & 2 & 0 & 0 & 5 & 17 \\
\hline Frequency $(\%)$ & & $(7.3)$ & $(54.7)$ & $(20.4)$ & $(1.5)$ & $(0.0)$ & $(0.0)$ & (3.6) & (12.4) \\
\hline \multicolumn{10}{|l|}{1999} \\
\hline Colorado & 11 & 0 & 11 & 0 & 0 & 0 & 0 & 0 & 0 \\
\hline Idaho & 84 & 6 & 31 & 2 & 0 & 0 & 0 & 0 & 45 \\
\hline Maine & 24 & 0 & 3 & 0 & 1 & 1 & 1 & 0 & 18 \\
\hline Minnesota & 58 & 4 & 54 & 0 & 0 & 0 & 0 & 0 & 0 \\
\hline Nebraska & 1 & 0 & 1 & 0 & 0 & 0 & 0 & 0 & 0 \\
\hline North Dakota & 14 & 3 & 11 & 0 & 0 & 0 & 0 & 0 & 0 \\
\hline Oregon & 32 & 3 & 28 & 0 & 1 & 0 & 0 & 0 & 0 \\
\hline Washington & 8 & 1 & 6 & 1 & 0 & 0 & 0 & 0 & 0 \\
\hline Totals for year & 232 & 17 & 145 & 3 & 2 & 1 & 1 & 0 & 63 \\
\hline Frequency (\%) & & (7.3) & $(62.5)$ & (1.3) & $(0.9)$ & $(0.4)$ & $(0.4)$ & $(0.0)$ & $(27.2)$ \\
\hline \multicolumn{10}{|l|}{2000} \\
\hline Colorado & 1 & 1 & 0 & 0 & 0 & 0 & 0 & 0 & 0 \\
\hline Delaware & 2 & 2 & 0 & 0 & 0 & 0 & 0 & 0 & 0 \\
\hline Idaho & 247 & 12 & 92 & 6 & 11 & 1 & 9 & 9 & 107 \\
\hline Maine & 15 & 0 & 1 & 0 & 1 & 0 & 3 & 2 & 8 \\
\hline Minnesota & 84 & 10 & 38 & 4 & 4 & 0 & 4 & 6 & 18 \\
\hline North Dakota & 7 & 6 & 1 & 0 & 0 & 0 & 0 & 0 & 0 \\
\hline Washington & 4 & 2 & 0 & 1 & 1 & 0 & 0 & 0 & 0 \\
\hline Wisconsin & 7 & 0 & 4 & 2 & 1 & 0 & 0 & 0 & 0 \\
\hline Totals for year & 367 & 33 & 136 & 13 & 18 & 1 & 16 & 17 & 133 \\
\hline Frequency (\%) & & $(9.0)$ & $(37.1)$ & (3.5) & (4.9) & $(0.3)$ & (4.4) & (4.6) & $(36.2)$ \\
\hline Survey totals & 805 & 67 & 382 & 71 & 29 & 2 & 17 & 22 & 215 \\
\hline Frequency $(\%)$ & & $(8.3)$ & $(47.5)$ & $(8.8)$ & (3.6) & $(0.2)$ & $(2.1)$ & $(2.7)$ & $(26.7)$ \\
\hline Group totals & 805 & & & 549 & & & 41 & & 215 \\
\hline Group frequency (\%) & & & & $(68.2)$ & & & (5.1) & & (26.7) \\
\hline
\end{tabular}


media amended with mefenoxam. The growth responses of many others fell somewhere between these values $\left(\mathrm{EC}_{50}\right.$ $0.05 \mu \mathrm{g} \mathrm{ml}^{-1}$ to $98.9 \mu \mathrm{g} \mathrm{ml}^{-1}$ ).

Levels of metalaxyl in tuber tissue can range from 0.01 to $0.04 \mu \mathrm{g} \mathrm{g}^{-1} 1$ month after harvest $(1,4,29)$, and it would logically follow that isolates able to grow at or above such levels in vitro could be identified and classified as resistant. Unfortunately, the case is not that simple. Host physiology, morphology, compartmentalization, and distribution of the compound within host tissue and the ability to maintain antifungal activity in vivo may all affect disease development, and as a result, the perceived sensitivity of the pathogen In studies involving Phytophthora species $(18,21,22,37,41), \mathrm{EC}_{50}$ values above 100 $\mu \mathrm{g} \mathrm{ml}{ }^{-1}$ were equated with resistance and those below $0.1 \mu \mathrm{g} \mathrm{ml}^{-1}$ with sensitivity. Similarly, since our work involves related but soilborne species, we consider isolates with in vitro $\mathrm{EC}_{50}$ values below $1.0 \mu \mathrm{g} \mathrm{ml}^{-1}$

Table 2. Distribution and ranking of $\mathrm{EC}_{50}$ values of Phytophthora erythroseptica isolates collected in 1991 and 1992

\begin{tabular}{|c|c|c|c|c|c|c|c|c|c|}
\hline \multirow[b]{3}{*}{ Year and source } & \multirow[b]{3}{*}{ No. isolates tested } & \multicolumn{8}{|c|}{ Distribution of isolate $\mathrm{EC}_{50}$ values $\left(\mu \mathrm{g} \mathrm{ml}^{-1}\right)$} \\
\hline & & \multicolumn{4}{|c|}{ Sensitive } & \multicolumn{3}{|c|}{ Intermediate } & \multirow{2}{*}{$\begin{array}{c}\text { Resistant } \\
\geq 100\end{array}$} \\
\hline & & $\leq \mathbf{0 . 0 5}$ & $0.06-0.1$ & 0.11-0.15 & 0.16-0.99 & 1.0-1.99 & $2.0-9.9$ & $10.0-99.9$ & \\
\hline \multicolumn{10}{|l|}{1991} \\
\hline Colorado & 3 & 0 & 1 & 1 & 1 & 0 & 0 & 0 & 0 \\
\hline Idaho & 1 & 1 & 0 & 0 & 0 & 0 & 0 & 0 & 0 \\
\hline Minnesota & 32 & 15 & 12 & 3 & 2 & 0 & 0 & 0 & 0 \\
\hline North Dakota & 1 & 0 & 0 & 0 & 1 & 0 & 0 & 0 & 0 \\
\hline Oregon & 2 & 1 & 1 & 0 & 0 & 0 & 0 & 0 & 0 \\
\hline Prince Edward Island, Canada & 2 & 1 & 1 & 0 & 0 & 0 & 0 & 0 & 0 \\
\hline Washington & 2 & 1 & 0 & 0 & 0 & 1 & 0 & 0 & 0 \\
\hline Wisconsin & 4 & 1 & 3 & 0 & 0 & 0 & 0 & 0 & 0 \\
\hline Totals for year & 47 & 20 & 18 & 4 & 4 & 1 & 0 & 0 & 0 \\
\hline Frequency $(\%)$ & & $(36.4)$ & $(45.4)$ & $(9.1)$ & $(9.1)$ & $(0.0)$ & $(0.0)$ & $(0.0)$ & $(0.0)$ \\
\hline \multicolumn{10}{|l|}{1992} \\
\hline Minnesota & 17 & 5 & 7 & 1 & 4 & 0 & 0 & 0 & 0 \\
\hline Idaho & 21 & 1 & 16 & 0 & 4 & 0 & 0 & 0 & 0 \\
\hline Totals for year & 38 & 6 & 23 & 1 & 8 & 0 & 0 & 0 & 0 \\
\hline Frequency $(\%)$ & & $(16.1)$ & $(54.8)$ & $(3.2)$ & $(25.8)$ & $(0.0)$ & $(0.0)$ & $(0.0)$ & $(0.0)$ \\
\hline Combined Total & 85 & 26 & 41 & 5 & 12 & 1 & 0 & 0 & 0 \\
\hline Frequency $(\%)$ & & $(28.7)$ & $(49.4)$ & (6.9) & $(13.8)$ & (1.1) & $(0.0)$ & $(0.0)$ & $(0.0)$ \\
\hline Group totals & 85 & & & 84 & & & 1 & & 0 \\
\hline Group frequency (\%) & & & & (98.9) & & & $(1.1)$ & & $(0.0)$ \\
\hline
\end{tabular}

Table 3. Distribution and ranking of $\mathrm{EC}_{50}$ values of Pythium ultimum isolates collected during a survey (1998 to 2000) of infected tubers obtained from the United States and Canada

\begin{tabular}{|c|c|c|c|c|c|c|c|c|c|}
\hline \multirow[b]{3}{*}{ Year and source } & \multirow[b]{3}{*}{ No. isolates tested } & \multicolumn{8}{|c|}{ Distribution of isolate $\mathrm{EC}_{50}$ values $\left(\mu \mathrm{g} \mathrm{ml}^{-1}\right)$} \\
\hline & & \multicolumn{4}{|c|}{ Sensitive } & \multicolumn{3}{|c|}{ Intermediate } & \multirow{2}{*}{$\begin{array}{c}\text { Resistant } \\
\geq 100\end{array}$} \\
\hline & & $\leq \mathbf{0 . 0 5}$ & 0.06-0.1 & 0.11-0.15 & $0.16-0.99$ & 1.0-1.99 & 2.0-9.9 & $10.0-99.9$ & \\
\hline \multicolumn{10}{|l|}{1998} \\
\hline Idaho & 11 & 5 & 5 & 0 & 0 & 0 & 0 & 0 & 1 \\
\hline Maine & 1 & 0 & 0 & 1 & 0 & 0 & 0 & 0 & 0 \\
\hline Minnesota & 19 & 3 & 8 & 7 & 1 & 0 & 0 & 0 & 0 \\
\hline North Dakota & 8 & 1 & 4 & 2 & 0 & 0 & 1 & 0 & 0 \\
\hline South Dakota & 3 & 0 & 3 & 0 & 0 & 0 & 0 & 0 & 0 \\
\hline Washington & 7 & 2 & 3 & 1 & 0 & 0 & 0 & 1 & 0 \\
\hline Wisconsin & 2 & 1 & 1 & 0 & 0 & 0 & 0 & 0 & 0 \\
\hline Totals for year & 51 & 12 & 24 & 11 & 1 & 0 & 1 & 1 & 1 \\
\hline Frequency $(\%)$ & & $(23.5)$ & $(47.1)$ & $(21.6)$ & $(2.0)$ & $(0.0)$ & $(2.0)$ & (2.0) & $(2.0)$ \\
\hline \multicolumn{10}{|l|}{1999} \\
\hline California & 1 & 1 & 0 & 0 & 0 & 0 & 0 & 0 & 0 \\
\hline Colorado & 2 & 0 & 2 & 0 & 0 & 0 & 0 & 0 & 0 \\
\hline Minnesota & 4 & 4 & 0 & 0 & 0 & 0 & 0 & 0 & 0 \\
\hline Oregon & 25 & 15 & 8 & 1 & 1 & 0 & 0 & 0 & 0 \\
\hline Washington & 14 & 4 & 6 & 0 & 3 & 0 & 0 & 1 & 0 \\
\hline Totals for year & 46 & 24 & 16 & 1 & 4 & 0 & 0 & 1 & 0 \\
\hline Frequency $(\%)$ & & $(53.7)$ & $(34.1)$ & $(0.0)$ & (7.3) & $(0.0)$ & $(0.0)$ & $(2.2)$ & $(0.0)$ \\
\hline \multicolumn{10}{|l|}{2000} \\
\hline British Columbia, Canada & 4 & 2 & 1 & 0 & 0 & 0 & 1 & 00 & \\
\hline Idaho & 6 & 1 & 5 & 0 & 0 & 0 & 0 & 0 & 0 \\
\hline Minnesota & 57 & 14 & 27 & 3 & 8 & 0 & 0 & 0 & 5 \\
\hline North Dakota & 9 & 1 & 7 & 0 & 1 & 0 & 0 & 0 & 0 \\
\hline Washington & 5 & 2 & 2 & 0 & 0 & 0 & 0 & 0 & 1 \\
\hline Wisconsin & 12 & 4 & 8 & 0 & 0 & 0 & 0 & 0 & 0 \\
\hline Totals for year & 93 & 24 & 50 & 3 & 9 & 0 & 1 & 0 & 6 \\
\hline Frequency (\%) & & $(25.8)$ & $(53.8)$ & $(3.8)$ & (7.3) & $(0.0)$ & $(1.1)$ & $(0.0)$ & $(6.5)$ \\
\hline Survey totals & 190 & 60 & 90 & 15 & 14 & 0 & 2 & 2 & 7 \\
\hline Frequency $(\%)$ & & $(31.6)$ & $(47.4)$ & (7.9) & (7.4) & $(0.0)$ & $(1.1)$ & $(1.1)$ & (3.7) \\
\hline Group totals & 190 & & & 179 & & & 4 & & 7 \\
\hline Group frequency (\%) & & & & $(94.2)$ & & & $(2.1)$ & & (3.7) \\
\hline
\end{tabular}


to be sensitive to the fungicide and those at $\mathrm{EC}_{50} 100 \mu \mathrm{g} \mathrm{ml}^{-1}$ or greater to be resistant. Isolates that fall between these two groups are considered "intermediate" types. This is consistent with the ranking ranges defined and characterized in a recent survey of metalaxyl resistance in the $P$. erythroseptica population collected from potatoes on Prince Edward Island (30). That study recognized three categories of sensitivity (metalaxyl sensitive, moderately metalaxyl resistant, highly metalaxyl resistant). The moderately resistant isolates appear to be intermediate in their responses to mefenoxam in vitro, but the level of resistance these isolates possess might be variable within a biological system particularly under field or storage conditions. Determination of the "biological significance" of the sensitivities of such isolates was not within the scope of the present study but should be addressed in future work.

Since a 2- to 3-year crop rotation cycle is typically employed in potato production, it is unlikely that individual sites (fields) were recurrently sampled during the course of this study. Therefore, although our data might imply that resistance is increasing temporarily in certain areas, the results are actually more indicative of the spatial distribution of resistance in the North American populations of these soilborne pathogens. Prior to our current work, a preliminary survey was undertaken in 1992 to ascertain the sensitivities of $P$. erythroseptica isolates from Minnesota, Wisconsin, and Idaho. All 46 isolates recovered and tested in that study were found to be sensitive to metalaxyl (38). However, soon after completion of that study, $P$. erythroseptica isolates insensitive to metalaxyl were discovered in Maine (23) and New York (13). We subsequently confirmed metalaxyl resistance in $P$. erythroseptica in Maine and documented the presence of resistant isolates in Idaho $(15,16,34)$. The results obtained with the comparative isolates appear to confirm the absence of mefenoxam resistance in these states prior to 1996. Resistance was found in two states (Maine and Idaho) during the first 3 years of the present study. However, with the 2000 survey, we report the occurrence of mefenoxam-resistant isolates of $P$. erythroseptica in Minnesota for the first time.

Results we obtained from testing a limited number of isolates from Canada suggest that the population may have been sensitive to mefenoxam prior to 1997. Peters et al. (30) in 2001, found that all 62 field isolates of $P$. erythroseptica obtained from the major potato growing area of Prince Edward Island remained highly sensitive to metalaxyl $\left(\mathrm{EC}_{50}<0.5 \mu \mathrm{g} \mathrm{ml}^{-1}\right)$. These results are encouraging because this is a high use area for mefenoxam. It is not likely that resistance would appear first in areas of minimum mefenoxam use.
We documented only a single case of resistance in Pythium ultimum in the first 3 years of this study (1997 to 1999). This isolate from Idaho represented only $1 \%$ of the total population tested over that time. In 2000, insensitive isolates were recovered from $6.4 \%$ of the population. This is a modest increase in the number of sites found to have insensitive isolates but these still represent a very small portion of the overall Pythium ultimum population. However, changes observed over the last 2 years of the survey suggest that the resistance to mefenoxam is becoming more widespread. This trend is particularly evident in Minnesota as 5 of 6 resistant isolates recovered in 2000 were from that state. Previous work with Pythium isolates collected from sugar beet in the Red River Valley from 1991 to 1993 found no evidence of resistance in the 97 isolates tested (2). The majority of the isolates we recovered from this area were also highly sensitive with $\mathrm{EC}_{50}$ values ranging between 0.05 $\mu \mathrm{g} \mathrm{ml}^{-1}$ and $0.99 \mu \mathrm{g} \mathrm{ml}^{-1}$.

The increase in the number of resistant isolates of P. erythroseptica and Pythium ultimum recovered from Minnesota, and the very high level of resistance they appear to possess is particularly alarming. Mefenoxan is still the only fungicide used to control leak and pink rot $(26,42)$, so significant problems controlling these diseases in that state may arise in the immediate future. Although the incidence of resistance remains low, we did find intermediate types at approximately the same frequency as the resistant types in the Pythium ultimum populations. These moderately insensitive isolates of $P$. erythroseptica and Pythium ultimum may be indicators of a population in transitional flux from sensitivity to resistance. Additional work is needed to determine the significance of this group.

Many of the infected tubers received in the survey came from fields and storages where fungicide apparently failed to control water rot. Thus, by design, our survey is probably skewed toward finding insensitivity within the pathogen population. As a result, our observations may not necessarily represent the frequency of resistance that exists in the field. These results only demonstrate that resistance exists in field populations of these water rot fungi collected from our survey areas. Further studies should be initiated to obtain soil populations of $P$. erythroseptica and Pythium ultimum and subsequently monitor the level of mefenoxam resistance in these populations, if effective control measures for pink rot and leak are to be maintained or developed.

The data presented here confirms that populations of mefenoxam insensitive isolates of $P$. erythroseptica are now present in the potato-growing areas of Maine, Idaho, and Minnesota. Displacement of mefenoxam-sensitive isolates may be due to the intense selection pressure provided by mefenoxam fungicide usage. The incidence of insensitivity to mefenoxam is still at a very low level in the North American population of Pythium ultimum relative to that of $P$. erythroseptica. However, the discovery of a significant number of resistant isolates of these pathogens in Minnesota in 2000 , demonstrates that insensitivity has reached detectable levels in the populations there. This should trigger concern and prompt adjustments in management practices directed toward the water rot pathogens. It is therefore, important to continue monitoring these areas, but it is also essential to survey other potato growing areas more extensively to assess the composition of the pathogen populations.

\section{ACKNOWLEDGMENTS}

We thank Phil Hamm for providing some of the isolates used in this study; the following individuals for supplying "water rot" infected tubers for our survey: P. Nolte, J. Fuller, P. Hamm, D. Johnson, S. Erickson, J. Vaadeland, D. Steevens, D. Lambert, W. Stevenson, R. Zink, L. Morrow, C. Larson, G. Taylor, T. Dayton, M. Bittner, D. Miller, G. McCoy, and J. Elmhirst; and Robert W. Stack for allowing us to access and test his collection of $P$. erythroseptica isolates. We also wish to gratefully acknowledge the financial support of Syngenta Crop Protection, Inc. and the statistical analysis assistance of Curt Doetkott. Without the support of our colleagues, this work would not have been possible.

\section{LITERATURE CITED}

1. Barak, E., Edgington, L. V., and Ripley, B. D. 1984. Bioactivity of the fungicide metalaxyl in potato tubers against some species of Phytophthora, Fusarium, and Alternaria, related to polyphenoloxidase activity. Can. J. Plant Pathol. 6: 304-308.

2. Brantner, J. R., and Windels, C. E. 1998 Variability in sensitivity to metalaxyl in vitro, pathogenicity, and control of Pythium spp. on sugar beet. Plant Dis. 82: 896-899.

3. Brent, K. J., and Hollomond, D. W. 1998. Fungicide resistance: The assessment of risk. FRAC Monograph No. 2., Global Crop Protection Federation, Brussels.

4. Bruin, G. C. A., Edgington, L. V., and Ripley, B. D. 1982. Bioactivity of the fungicide metalaxyl in potato tubers after foliar sprays. Can. J. Plant Pathol. 4:353-356.

5. Coffey, D. M., and Bower, L. A. 1984. In vitro variability among isolates of six Phytophthora species in response to metalaxyl. Phytopathology 74:502-506.

6. Cook, R. J., and Zhang, B.-X. 1985. Degree of sensitivity to metalaxyl within the Pythium spp. pathogenic to wheat in the Pacific Northwest. Plant Dis. 69:686-688.

7. Davidse, L. C., Hofman, A. E., and Velthuis, G. C. M. 1983. Specific interference of metalaxyl with endogenous RNA polymerase activity in isolated nuclei from Phytophthora megasperma f. sp. medicaginis. Exp. Mycol. 7:344-361.

8. Davidse, L. C., Looyen, D., Turkensteen, L. J., and Van der Wal, D. 1981. Occurrence of metalaxyl-resistant strains of Phytophthora infestans in Dutch potato fields. Neth. J. Plant Pathol. 87:65-68.

9. Dowley, L. J., and O'Sullivan, E. 1981 Metalaxyl-tolerant strains of Phytophthora infestans (Mont.) De Bary in Ireland. Potato Res. 24:417-421.

10. Draper, N. H., and Smith, H. 1981. Applied Regression Analysis, 2nd ed. John Wiley \& 
Sons, New York

11. Ferrin, D. M., and Kabashima, J. N. 1991. In vitro sensitivity to metalaxyl of isolates of Phytophthora citricola and P. parasitica from ornamental hosts in southern California. Plant Dis. 75:1041-1044.

12. Fraser, D. E., Shoemaker, P. B., and Ristaino, J. B. 1999. Characterization of isolates of Phytophthora infestans from tomato and potato in North Carolina from 1993-1995. Plant Dis. 83:633-638.

13. Goodwin, S. B., and McGrath, M. T. 1995. Insensitivity to metalaxyl among isolates of Phytophthora erythroseptica. Plant Dis. 79:967.

14. Goss, R. W. 1949. Pink rot of potato caused by Phytophthora erythroseptica Pethyb. Univ. Nebr., Coll. Agric., Agric. Exp. Stn. Res. Bull. 160. Lincoln, Nebraska.

15. Gudmestad, N. C., Salas, B., Secor, G. A., Taylor, R. J., and Doetkott, C. 2000. Sensitivity of North American isolates of Phytophthora erythroseptica and Pythium ultimum to mefenoxam (Ridomil Gold EC). (Abstr.) Am. J Potato Res. 77:417-418.

16. Gudmestad, N. C., Salas, B., Taylor, R. J., and Rivera, V. V. 2000. Assessment of mefenoxam resistance in Phytophthora erythroseptica in the USA. Proc. Brighton Crop Prot. Conf. 2000 - Pests and Diseases 2:435-440.

17. Ho, H. H., and Jong, S. C. 1989. Phytophthora erythroseptica. Mycotaxon 36:7390.

18. Hunger, R. M., Hamm, P. B., Horner, C. E., and Hansen, E. M. 1982. Tolerance of Phytophthora megasperma isolates to metalaxyl. Plant Dis. 66:645-649.

19. Jeffers, S. N., and Martin, S. B. 1986. Comparison of two selective media for Phytophthora and Pythium spp. Plant Dis. 70:1038-1043.

20. Jones, W. 1935. Soft rot of potatoes caused by Pythium ultimum Trow. Sci. Agric. 15:402410.

21. Kadish, D., and Cohen, Y. 1988. Fitness of Phytophthora infestans isolates from metalaxyl-sensitive and -resistant popula- tions. Phytopathology 78:912-915.

22. Kadish, D., and Cohen, Y. 1988. Estimation of metalaxyl resistance in Phytophthora infestans. Phytopathology 78:915-919.

23. Lambert, D. H., and Salas, B. 1994. Metalaxyl insensitivity of Phytophthora erythroseptica isolates causing pink rot of potato in Maine. Plant Dis. 78:1010.

24. Merkens, C. L., Stack, R. W., Gudmestad, N. C., and Secor, G. A. 1995. Occurrence of pink rot on both irrigated and non-irrigated potatoes in 1994. (Abstr.) Phytopathology $85: 1045$.

25. Morton, H. V., and Urech, P. A. 1988. History of the development of resistance to phenylamide fungicides. Pages 59-60 in: Fungicide Resistance in North America. C. E. Delp, ed. American Phytopathological Society, St. Paul, $\mathrm{MN}$.

26. Mulrooney, R. P. 1982. Evaluation of ridomil for pink rot and leak control, 1981. Fungic. Nematicide Test 37:78.

27. Parra, G., and Ristaino, J. B. 2001. Resistance to mefenoxam and metalaxyl among field isolates of Phytophthora capsici causing Phytophthora blight of bell pepper. Plant Dis. 85:1069-1075

28. Plaats-Niterink, A. J. Van der. 1981. Monograph of the genus Pythium. Stud. Mycol. 21:1-242.

29. Platt, H. W. 1994. Foliar application of fungicides affects occurrence of potato tuber rots caused by four foliar pathogens. Can. J. Plant Pathol. 16:341-346.

30. Peters, R. D., Sturz, A. V., Matheson, B. G., and Malone, A. 2001. Metalaxyl sensitivity of isolates of Phytophthora erythroseptica in Prince Edward Island. Plant Pathol. 50:302309.

31. Powelson, M. L., Johnson, K. B., and Rowe, R. C. 1993. Management of diseases caused by soilborne pathogens. Pages 149-158 in: Potato Health Management. R. C. Rowe, ed. American Phytopathological Society, St. Paul, MN.

32. Ratkowsky, D. A. 1983. Nonlinear Regression Modeling. Marcel Dekker, New York.
33. Reuveni, M., Eyal, M., and Cohen, Y. 1980. Development of resistance to metalaxyl in Pseudoperonospora cubensis. Plant Dis. 64:1108-1109.

34. Salas, B., Secor, G. A., and Gudmestad, N. C. 1998. Sensitivity of Phytophthora erythroseptica to metalaxyl. (Abstr.) Am. J. Potato Res. 75:297

35. Sanders, P. L. 1984. Failure of metalaxyl to control Pythium blight on turfgrass in Pennsylvania. Plant Dis. 68:776-777.

36. Secor, G. A., and Gudmestad, N. C. 1999. Managing fungal diseases of potato. Can. J. Plant Pathol. 21:213-221.

37. Sozzi, D., and Staub, T. 1987. Accuracy of methods to monitor sensitivity of Phy tophthora infestans to phenylamide fungicides. Plant Dis. 71:422-425.

38. Stack, R. W., Salas, B., Gudmestad, N. C., and Secor, G. A. 1993. The lack of evidence for metalaxyl tolerance in Phytophthora erythroseptica, the cause of pink rot of potato. (Abstr.) Phytopathology 83:886.

39. Staub, T., Dahmen, H., Urech, P., and Schwinn, F. 1979. Failure to select for in vitro resistance in Phytophthora infestans to acylalanine fungicides. Plant Dis. Rep. 63:385-389.

40. Sujkowski, L. S., Fry, B. A., Power, R. J., Goodwin, S. B., Peever, T. L., Hamlen, R. A., and Fry, W. E. 1995. Sensitivities of Mexican isolates of Phytophthora infestans to chlorothalonil, cymoxanil, and metalaxyl. Plant Dis. 79:1117-1120.

41. Timmer, L. W., Graham, J. H., and Zitko, S. E. 1998. Metalaxyl-resistant isolates of Phytophthora nicotianae: occurrence, sensitivity, and competitive parasitic ability on citrus Plant Dis. 82:254-261.

42. White, J. G., Stanghellini, M. E., and Ayoubi, L. M. 1988. Variation in the sensitivity to metalaxyl of Pythium spp. isolated from carrot and other sources. Ann. Appl. Biol 113:269-277.

43. Wicks, T. J., Davoren, C. W., and Hall, B. H. 2000. Fungicidal control of Phytophthora erythroseptica: The cause of pink rot on potato. Am. J. Potato Res. 77:233-240. 